\title{
Tandem Mass Spectrometry for the Structural Determination of Backbone-Modified Peptides
}

\author{
Leesa J. Deterding and Kenneth B. Tomer \\ Laboratory of Molecular Biophysics, National Institute of Environmental Health Sciences, Research Triangle \\ Park, North Carolina, USA
}

Arno F. Spatola

Department of Chemistry, University of Louisville, Louisville, Kentucky, USA

\begin{abstract}
A variety of backbone-modified peptides were desorbed by fast atom bombardment and collisionally activated. These peptide modifications involve the replacement of a normal [CONH] peptide linkage with such groups as thiomethylene ether $\left(\mathrm{CH}_{2} \mathrm{~S}\right)$, thioamide $(\mathrm{CSNH})$, methyleneamine $\left(\mathrm{CH}_{2} \mathrm{NH}\right)$, and thiomethylene sulfoxide $\left(\mathrm{CH}_{2} \mathrm{SO}\right)$ moieties. Modified linear peptides decompose to give fragmentations characteristic of the modifications as well as typical peptide bond fragments. The presence of a replacement group in cyclic peptides can induce new fragmentations. The presence of other functional groups, such as an exocyclic $\mathrm{N}$-terminal residue, however, can dominate the observed fragmentations. Upon collisional activation, unmodified linear peptides fragment to give $\mathrm{N}$-terminal ions as the most abundant daughter ions. In comparison, $\psi\left[\mathrm{CH}_{2} \mathrm{NH}\right]$ and $\psi\left[\mathrm{CH}_{2} \mathrm{~S}\right]$ modified linear peptides decompose to give prominent $\mathrm{C}$-terminal sequence ions. The $\psi\left[\mathrm{CH}_{2} \mathrm{SO}\right]$ modified linear peptides, however, fragment into both $\mathrm{N}$ - and $\mathrm{C}$-terminal ions of high relative abundance. Depending on the modification, daughter ions or internal fragment ions are observed that are characteristic of the amide bond replacement. Useful structural information can therefore be obtained. $(J$ Am Soc Mass Spectrom 1990, 1, 174-182)
\end{abstract}

I $t$ has been shown recently by Spatola et al. [1-7] that variations in the backbone elements in peptides are useful for determining the functional role of the normal $[\mathrm{CONH}]$ peptide linkage. These variations include the replacement of [CONH] bonds in linear and cyclic peptides with such groups as thiomethylene ether $\left(\mathrm{CH}_{2} \mathrm{~S}\right)$, thiomethylene sulfoxide $\left(\mathrm{CH}_{2} \mathrm{SO}\right)$, thioamide $(\mathrm{CSNH})$, and methyleneamine $\left(\mathrm{CH}_{2} \mathrm{NH}\right)$ moieties. The effects of such modifications include (1) enhanced receptor selectivity, (2) increased resistance to enzymatic degradation, and (3) altered solubility properties.

In one example, modified cyclic peptides containing a $\psi\left[\mathrm{CH}_{2} \mathrm{~S}\right]$ amide bond replacement show a higher potency for $\delta$ receptors than the corresponding cyclic parent peptide [2]. It was proposed that because the rotational energy barrier for a $\mathrm{CH}_{2} \mathrm{~S}$ bond is lower than that of an amide bond, the cyclic pseudopeptides contain more flexible ring structures. Therefore, this enhanced flexibility may be the reason for the relatively high potency toward both $\mu$ and $\delta$ receptor classes. In comparison, linear pseudopeptides containing the

Address reprint requests to Kenneth B. Tomer, Laboratory of Molecular Biophysics, National Institute of Environmental Health Sciences, P.O. Box 12233, Research Triangle Park, NC 27709. thiomethylene substitution show a decrease in both potency and receptor selectivity [3].

In addition, the position of the amide bond replacement has an effect on the receptor affinity. For example, in comparing the receptor selectivity of a peptide modified with a thioamide linkage at the second peptide bond versus that of one modified at the fourth peptide bond, the former selectively strengthens binding to the $\delta$ receptor whereas the latter shows very little difference in selectivity from that of the parent peptide [4]. This suggests, therefore, that the C-terminal portion of the peptide has little influence on the relative receptor affinity of the peptide [4].

Benovitz and Spatola [8] also studied the effect of amide bond replacements with respect to resistance toward enzymatic degradations. The presence of a thiomethylene ether replacement apparently offers enzymatic degradation protection to amide bonds several residues removed from the originally labile linkages. Where manipulation of side-chain elements in peptides has traditionally been used to achieve such properties as decreased enzyme resistance or enhanced biological activities, modifications in the backbone chains of peptides may provide an alternative mechanism for obtaining similar biological responses.

The development of mass spectrometry for the 
structure determination and amino acid sequencing of peptides has been an active area of research for many years and has been recently reviewed $[9,10]$. A variety of ionization techniques have been utilized in an effort to characterize these biomolecules. Early studies of peptides involved electron ionization (EI) and chemical ionization $(\mathrm{CI})$ mass spectrometry as a means of analysis. However, chemical derivatizations (i.e., permethylation and reduction to polyamino alcohols) were often necessary to make these polar molecules more amenable to EI and CI. Another disadvantage is that both methods are limited to small (i.e., deca-) peptides. To overcome these disadvantages, researchers turned to other desorption techniques. Field desorption (FD) and plasma desorption (PD) have demonstrated the capability of ionizing polar biomolecules such as peptides [11-15]. These techniques are advantageous because no derivatizations are necessary and very large peptides can be analyzed. However, PD requires special instrumentation, and FD is not a routine technique.

Since its inception, fast atom bombardment mass spectrometry (FAB/MS) [16] has become a widely used desorption technique for the analysis of peptides [9, 10]. In addition, the FAB/MS analysis of backbonemodified peptides [17] has become very useful, because these pseudopeptides cannot be identified in an Edman degradation. However, there are several disadvantages associated with FAB/MS for the structural elucidation of biomolecules. First, mass spectra can be complicated by the high level of chemical background noise and, second, often few structurally informative fragment ions are produced. Therefore, FAB in conjunction with tandem mass spectrometry (FAB/MS/MS) has been developed to alleviate some of these problems associated with $\mathrm{FAB} / \mathrm{MS}$.

In coupling FAB with MS/MS, the ion of interest is focused through the first-stage spectrometer (MS-I) into a collision cell and is collisionally activated to form its daughter ions. The fragment ions are subsequently analyzed by scanning the second-stage spectrometer (MS-II). The resulting collision-activated decomposition (CAD) spectra often reveal structural information. Since the early reports on the application of the combined techniques of FAB and MS/MS for the determination of peptides [18-20], FAB/MS/MS has become widely used for the analysis of linear peptides (see refs 21-29 for representative papers), and the area has recently been reviewed $[9,28,29]$. It has been useful not only for the sequence determination of linear peptides, but also for the determination of cyclic peptides $[9,28-34]$, which are very difficult to sequence by traditional mass spectrometric techniques. Fast atom bombardment coupled with MS/MS offers several advantages for the analysis of peptides:

1. The need for the complete separation of peptide mixtures is eliminated.

2. The technique is applicable to N-blocked peptides as well as those containing modified amino acids.
3. Information is obtained from both $\mathrm{N}$ - and Cterminal sequences.

4. Matrix ions are eliminated.

5. Parent ion-daughter ion relationships in mixtures can be determined.

As part of our continuing interest in the application of FAB/MS/MS for the structural determination of biomolecules [35-38], we investigated the CAD spectra of several backbone-modified peptides. These compounds cannot be sequenced by normal biochemical techniques such as Edman degradation. Thus, it would be extremely useful if these types of modifications could be determined by FAB/MS/MS. We now report the results of our study.

\section{Experimental}

\section{Chemicals}

The peptides used in this study are listed in Table 1. The "psi bracket" is representative of the nomenclature of amide bond replacements in peptides [1]. The $\psi$ placed between two amino acids signals the absence of the normal CONH linkage, and the replacing chemical moiety is specified within the bracket.

Peptides and pseudopeptides used in this study were synthesized by solution and solid-phase methods [2-7]. All products were purified by a combination of open-column and high-performance liquid chromatography (HPLC) procedures, and purity was established by a different set of analytical HPLC parameters as well as by thin layer chromatography in at least two solvent systems. In some cases, products were prepared by two different routes (e.g., cyclization of different linear precursors to a common ring) to verify both structural and stereochemical integrity. Although the sulfoxides $\left(\psi\left[\mathrm{CH}_{2} \mathrm{SO}\right]\right)$ are configurationally stable and the diastereomeric pseudopeptides have in most cases been separable, the absolute configurations of these centers have not yet been established. The $\psi\left[\mathrm{CH}_{2} \mathrm{NH}\right]$ analogues were separated and characterized as their acetate salts. Additional details regarding structural and conformational properties of these analogues are being collected and will be published elsewhere.

\section{Mass Spectrometry}

All mass spectra were acquired on a VG ZAB-4F mass spectrometer of $B_{1} E_{1}-E_{2} B_{2}$ geometry that has been previously described [39]. This instrument is operated at $8 \mathrm{kV}$ and is equipped with an Ion Tech saddlefield atom gun and a standard VG FAB source. The samples (approximately $1 \mu \mathrm{L}$ of a $1 \mathrm{mg} / \mathrm{mL}$ solution) were dissolved in dithiothreitol/dithioerythritol matrix on the FAB probe tip and bombarded with 8-keV xenon atoms. Full-scan mass spectra were obtained by scanning MS-I with detection at the second multiplier in the third field-free region. Daughter ion spectra were acquired by collisional activation (CA) at $8 \mathrm{kV}$. The par- 
Table 1. Backbone-modified peptides studied by tandem mass spectrometry

\begin{tabular}{|c|c|}
\hline$\left[\mathrm{CH}_{2} \mathrm{NH}\right]-$ Modified peptide & {$\left[\mathrm{CH}_{2} \mathrm{~S}\right]-$ Modified peptide } \\
\hline Tyr-D-Ala-Gly-Phe $\psi$ Leu & Tyr-D-Ala-Gly $\psi$ Phe-Leu \\
\hline Boc-Gly $\psi$ Phe-OMe & Tyr-D-Ala-Gly-Phe $\psi$ Leu-Arg-Arg-Ile \\
\hline Boc-Gly $\psi$ Phe-OH & Fmoc-Tyr-D-Lys-Gly $\psi$ Phe-Leu \\
\hline Boc-D-Lys $(\epsilon-C b z)-G l y \psi$ Phe-OMe & Fmoc-Tyr-D-Lys-Gly $\psi$ Phe \\
\hline Tyr-c[D-Lys-Gly-Phe $\psi$ Leu] & c[D-Lys-Gly-Phe $\psi$ Leu $]$ \\
\hline \multirow[t]{2}{*}{ Tyr $\psi$-c[D-Lys-Gly-Phe-Leu] } & Tyr-c[D-Lys-Gly-Phe $\psi$ Leu] \\
\hline & $\begin{array}{l}\text { Tyr-c[D-Lys-Gly } \psi \text { Phe-Leu] } \\
\text { c[Phe-Pro } \psi \text { Gly-Pro-Gly] }\end{array}$ \\
\hline [CSNH]-Modified peptide & {$\left[\mathrm{CH}_{2} \mathrm{SO}\right]-$ Modified peptide } \\
\hline Pro $\psi$ Gly-Phe-Pro-Gly & Tyr-D-Ala-Gly $\psi$ Phe-Leu \\
\hline Boc-Gly $\psi$ Phe-OMe & Tyr-D-Ala-Gly-Phe $\psi$ Leu-Arg-Arg-lle \\
\hline Cbz-Leu-Gly $\psi$ Leu-OMe & Tyr-c-[D-Lys-Gly $\psi$ Phe-Leu] \\
\hline c[D-Lys-Gly $\psi$ Phe-Leu] & Tyr-c[D-Lys-Gly-Phe $\psi$ Leu] \\
\hline Tyr-c[D-Lys-Gly $\psi$ Phe-Leul & \\
\hline
\end{tabular}

ent ions were collided with helium gas ( $50 \%$ parent ion beam reduction) in the collision cell between MS-I and MS-II. The resulting CAD spectra were obtained by a linear scan of $E_{2} B_{2}$ in a linked mode. Computerized mass assignments based on a linear scan function of $B_{2}$ were used for mass calibration. These assignments were verified by comparison with the mass spectra and by manual mass marking [37]. The data acquisition system used was a VG Analytical 11-250 data system.

\section{Results and Discussion}

For the purposes of this discussion, we will focus on the MS/MS spectrum of a single modified peptide that is typical of its class. The fragmentation observed will be compared to those of the corresponding unmodified peptide, and the impact of the backbone modification on the structural determination of these peptides will be discussed.

\section{Sequencing of Peptides}

Upon $\mathrm{CA}$, the $[\mathrm{M}+\mathrm{H}]^{+}$ions of unmodified linear peptides typically fragment into daughter ions by cleavage of the peptide backbone. The MS/MS spectrum of the $[\mathrm{M}+\mathrm{H}]^{+}$ion of the peptide Tyr-D-Ala-Gly-Phe-Leu is shown as an example in Figure 1a. The majority of the fragment ions observed result from peptide bond cleavage with charge retention on the $\mathrm{N}$-terminal (i.e., $\mathrm{a}_{n}, \mathrm{~b}_{n}$, and $\mathrm{c}_{n}$ sequence ions) and the C-terminal (i.e., $\mathrm{x}_{n}, \mathrm{y}_{n}$, and $\mathrm{z}_{n}$ sequence ions) portions of the molecule with a complete $\mathrm{N}$-terminal sequence being observed. It has been reported previously that observance of both $\mathrm{N}$ - and C-terminal ions is common in peptides that lack a basic amino acid residue (i.e., Lys or Arg) at or near a terminus [40].

The nomenclature for the peptide cleavages is that of Roepstorff and Fohlman [41] as modified by Biemann [27]. Ions due to internal fragments are designated by the $\mathrm{N}$-terminal cleavage and $\mathrm{C}$-terminal cleav- age yielding the fragment, for example, $y_{3} b_{5}$. Note that this nomenclature indicates an $\mathrm{N}$-terminal $\mathrm{NH}_{2}$ group and a C-terminal charged group such as an acylium ion. In all cases, the left-hand amino acid residue in the structures given in Table 1 is designated as the Nterminal amino acid, and the right-hand amino acid residue is designated as the C-terminal. For example, for the pseudopeptide c[D-Lys-Gly-Phe $\psi$ Leu], Lys is the first amino acid residue, and for the pseudopeptide Tyr-c[D-Lys-Gly-Phe $\psi$ Leu], Tyr is the first amino acid residue. Fragments in which the pseudopeptide bond is broken are indicated by inclusion of a $\psi$, as in $\mathrm{y}_{3} \psi \mathrm{b}_{4}$.

In contrast to that of linear peptides, the sequencing of cyclic peptides is much more difficult. It has been reported $[32,33]$ that the major daughter ions can be interpreted in terms of protonation on a peptide nitrogen. Following protonation, a linear acylium ion is formed owing to opening of the peptide ring. Losses of amino acid residues from the C-terminus are then observed. For example, the spectrum of the $[\mathrm{M}+\mathrm{H}]^{+}$ion of the cyclic peptide Tyr-c[D-Lys-GlyPhe-Leu] (Figure 1b) contains fragments $y_{3}$, which can be formally envisioned as arising from protonation of glycine, ring opening, and loss of Tyr-Lys-Leu and $b_{3}$ arising from protonation on $\epsilon$-Lys, ring opening and loss of Phe-Leu. The relatively abundant fragment ion $x_{n}$ (not usually observed in linear peptides) is a result of the cyclic peptide $[\mathrm{M}+\mathrm{H}]^{+}$ion undergoing $\alpha$ cleavage of the $\mathrm{C}-\mathrm{C}$ bond adjacent to the exocyclic Nterminal group with hydrogen migration. This observation can be used to identify an exocyclic $\mathrm{N}$-terminal amino acid residue.

\section{Methyleneamine $\left(\mathrm{CH}_{2} \mathrm{NH}\right)$ Substitution}

The CA spectrum for the modified straight-chain peptide Tyr-D-Ala-Gly-Phe $\psi\left[\mathrm{CH}_{2} \mathrm{NH}\right]$ Leu is shown in Figure $2 \mathrm{a}$. The $[\mathrm{M}+\mathrm{H}]^{+}$ion of the modified peptide frag- 

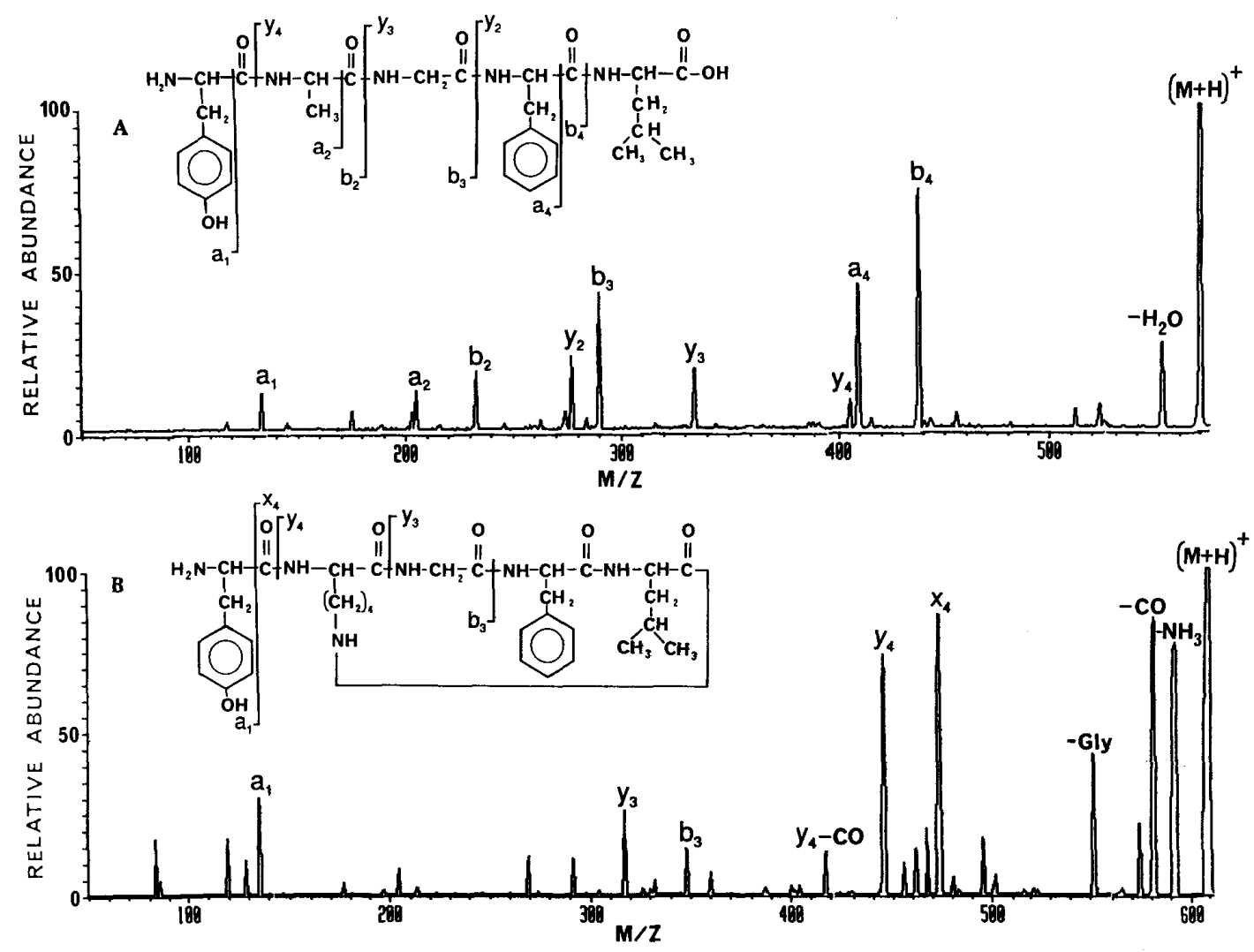

Figure 1. CAD spectra of the $[\mathrm{M}+\mathrm{H}]^{+}$ions of (a) the unmodified straight-chain peptide Tyr-DAla-Gly-Phe-Leu and (b) the unmodified cyclic peptide Tyr-c[D-Lys-Gly-Phe-Leu].

ments to give ions that contain the methyleneamino group in high relative abundance. For example, the Cterminal ions $\mathrm{y}_{3}$ and $\mathrm{y}_{4}$, which contain the secondary amine, are observed in Figure 2a. In comparison, the unmodified parent peptide (Figure 1a) decomposes upon CA to give relatively abundant N-terminal ions (i.e., $a_{4}, b_{3}$, and $b_{4}$ ) and the relatively low abundance ions $y_{3}$ and $y_{4}$. Another major difference that should be noted is that the $\mathrm{N}$-terminal ion $\mathrm{c}_{4}$, a low-abundance ion in the decomposition of the parent peptide, is now present in high abundance in the CA spectrum of the pseudopeptide. This $c_{4}$ ion is a result of cleavage of the $\mathrm{NH}-\mathrm{CH}$ bond where the $\mathrm{NH}$ results from substitution of the $\left[\mathrm{CH}_{2} \mathrm{NH}\right]$ group. This same fragmentation was observed by Lippstreu-Fisher and Gross [42] in the CAD spectra of polyamino alcohols. Owing to the presence of the $\left[\mathrm{CH}_{2} \mathrm{NH}\right]$ replacement moiety, an internal fragment ion at $m / z 191$, fragment $y_{3}{ }^{\psi} b_{4}$ in Figure $2 \mathrm{a}$, is observed and is the result of $\alpha$. cleavage of the $\mathrm{CH}_{2}-\mathrm{NH}$ bond of the substituted methylene group.

The MS/MS spectra of the $\left[\mathrm{CH}_{2} \mathrm{NH}\right]$ modified cyclic peptides, for example, Tyr-c[D-Lys-GlyPhe $\left.\psi\left[\mathrm{CH}_{2} \mathrm{NH}\right] \mathrm{Leu}\right]$ (Figure $2 \mathrm{~b}$ ), do not differ as significantly from that of the unmodified cyclic peptides as in the case of the linear peptides, possibly because of the presence of the exocyclic N-terminal group. The $x_{4}$ and $\mathrm{y}_{4}$ ions (C-terminal sequence ions) arising by loss of the exocyclic residue are still of high relative abundance. Two new fragment ions, $\mathrm{y}_{3} \mathrm{a}_{5}$ and $\mathrm{y}_{3} \mathrm{~b}_{4}(\mathrm{~m} / \mathrm{z}$ 276 and 191, respectively), which contain the modified $\left[\mathrm{CH}_{2} \mathrm{NH}\right]$ bond, appear.

\section{Thioamide (CSNH) Substitution}

Replacement of a [CONH] group in the backbone chain with a $[\mathrm{CSNH}]$ moiety seems to have little effect on the fragmentation of the peptide. As an example, the $[\mathrm{M}+$ $\mathrm{H}]^{+}$ion of the modified peptide Pro $\psi[\mathrm{CSNH}]$ Gly-PhePro-Gly fragments when activated to give a relatively simple daughter ion spectrum (Figure 3 ). Amino acid sequence ions are observed (i.e., $b_{2}, b_{3}, y_{2}$, and $y_{3}$ ) and are of relatively high abundance. Novel cleavages due to the presence of the thioamide moiety are of low relative abundance if present at all. Thus the thioamide bond behaves similarly to the amide bond.

\section{Thiomethylene Ether $\left(\mathrm{CH}_{2} \mathrm{~S}\right)$ Substitution}

Upon CA, pseudopeptides that have been modified by a $\left[\mathrm{CH}_{2} \mathrm{~S}\right]$ replacement group fragment to give $\mathrm{C}$ terminal ions in high relative abundance. The $[\mathrm{M}+\mathrm{H}]^{+}$ ion of Tyr-D-Ala-Gly $\psi\left[\mathrm{CH}_{2}\right.$ S]Phe-Leu (Figure $4 \mathrm{a}$ ) de- 

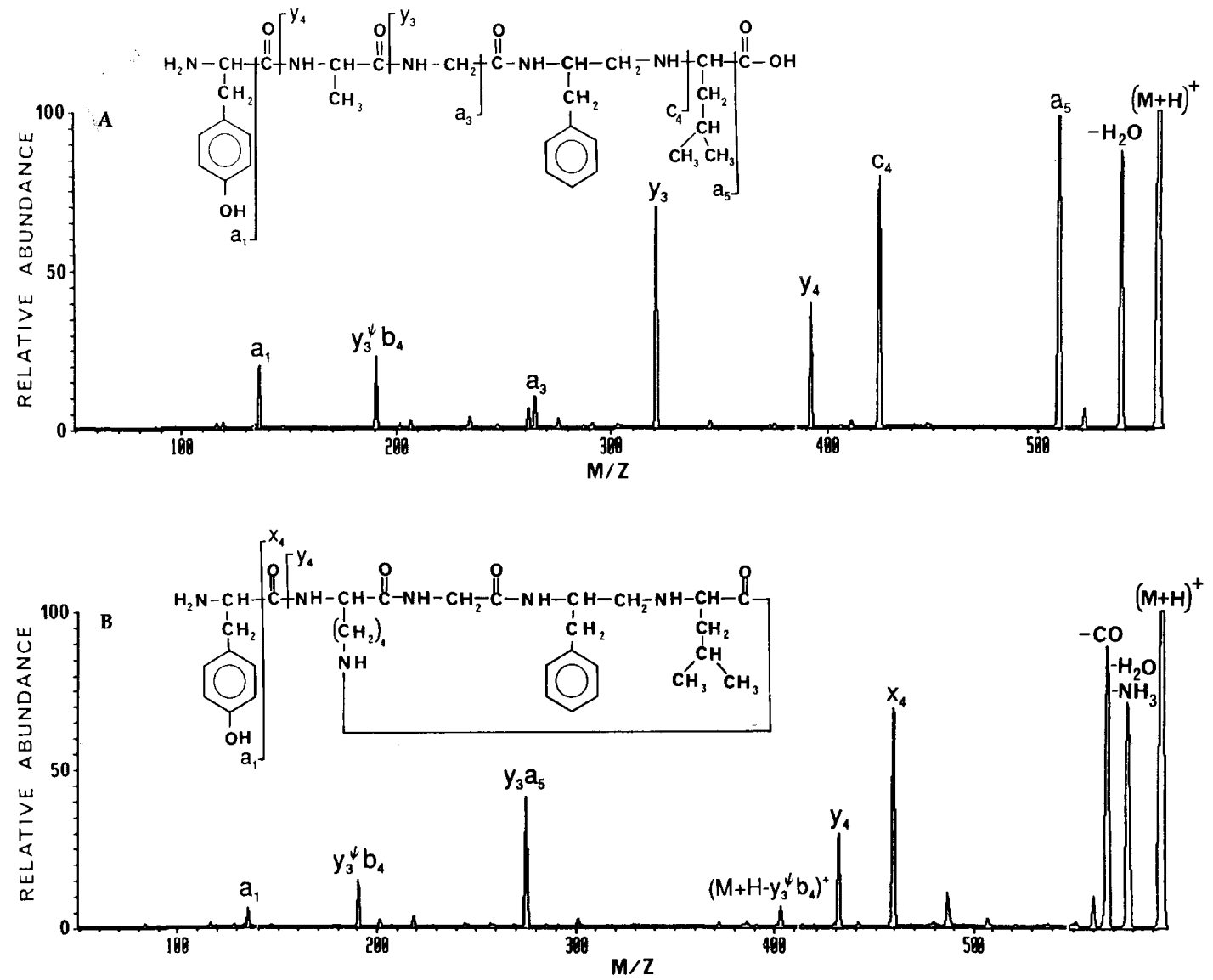

Figure 2. CAD spectra of the $[\mathrm{M}+\mathrm{H}]^{+}$ions of (a) the modified peptide Tyr-D-Ala-Gly-

$\mathrm{Phe} \psi\left[\mathrm{CH}_{2} \mathrm{NH}\right] \mathrm{Leu}$; and (b) the modified cyclic peptide Tyr-c[D-Lys-Gly-Phe $\left.\psi\left[\mathrm{CH}_{2} \mathrm{NH}\right] \mathrm{Leu}\right]$.



Figure 3. CAD spectrum of the $[\mathrm{M}+\mathrm{H}]^{+}$ion of the modified peptide Pro $\psi[\mathrm{CSNH}] \mathrm{Gly}$-Phe-ProGly. 

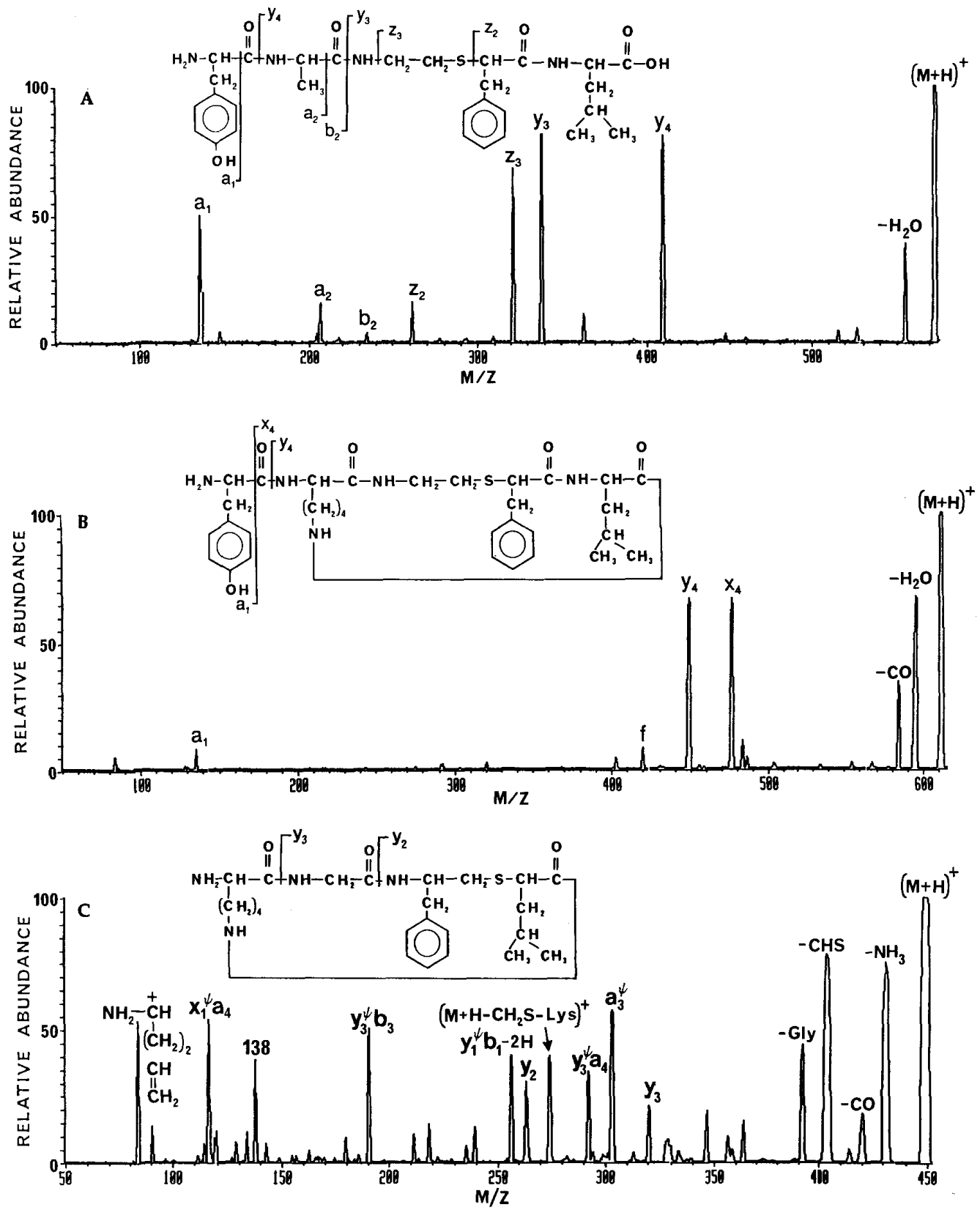

Figure 4. CAD spectra of the $[\mathrm{M}+\mathrm{H}]^{+}$ions of (a) Tyr-D-Ala-Gly $\psi\left[\mathrm{CH}_{2} \mathrm{~S}\right]$ Phe-Leu, (b) Tyr-c[D-Lys$\left.\mathrm{Gly} \psi\left[\mathrm{CH}_{2} \mathrm{~S}\right] \mathrm{Phe}-\mathrm{Leu}\right]$, and (c) c[D-Lys-Gly-Phe $\psi\left[\mathrm{CH}_{2} \mathrm{~S}\right]$ Leu].

composes into the abundant ions of $y_{3}$ and $y_{4}$. The enhancement of these fragmentations, compared to the CA spectrum of the parent peptide (Figure 1a), is similar to that observed in the $\left[\mathrm{CH}_{2} \mathrm{NH}\right]$-modified peptide (Figure 2a). However, a major fragment ion that was not observed in the previous spectra is the daughter ion formed as a result of cleavage of the $\mathrm{NH}-\mathrm{CH}_{2}$ linkage (i.e., fragment $z_{3}$ ) two bonds removed from the $\mathrm{CH}_{2} \mathrm{~S}$ bond. This fragmentation may occur with partic- ipation of the sulfur to form a product ion containing a three-membered ring (Scheme I). This process is characteristic of the presence of the $\left[\mathrm{CH}_{2} \mathrm{~S}\right]$ modification.

The MS/MS spectra of $\left[\mathrm{CH}_{2} \mathrm{~S}\right]$-modified cyclic peptides with an exocyclic Tyr group are similar to the MS/MS spectra of unmodified and $\left[\mathrm{CH}_{2} \mathrm{NH}\right]$-modified cyclic peptides in that the cyclic peptides tend to fragment into C-terminal ions $x_{4}$ and $y_{4}$ as well as into N-terminal sequence ions such as those of $\mathrm{m} / \mathrm{z} 293$ 


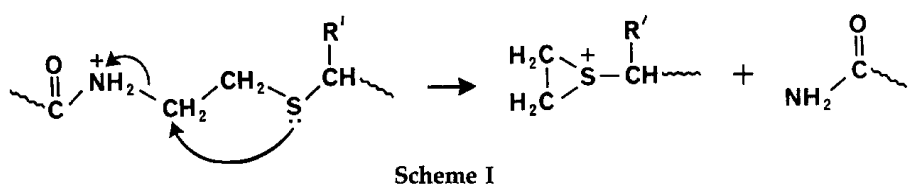

$\left(y_{3} a_{5}\right)$ and $m / z 321\left(y_{3} b_{5}\right)$ (Figure $\left.4 b\right)$. The presence of the N-terminal substituent, the loss of which gives rise to the $\mathrm{C}$-terminal $\mathrm{x}$ and $\mathrm{y}$ fragments, presumably promotes the observation of the C-terminal ions. In the absence of this substituent, that is, in the case of c[Lys-Gly-Phe $\psi$ Leu] as shown in Figure 4c, N-terminal ions are more abundant, which is similar to unmodified cyclic peptides that undergo CA to yield predominantly N-terminal sequence ions [24, 25]. In addition, several unusual fragment ions arising from the presence of the $\left[\mathrm{CH}_{2} \mathrm{~S}\right]$ group are observed (i.e., $m / z 275$, $\left[\mathrm{M}+\mathrm{H}-\mathrm{CH}_{2} \mathrm{~S}-\mathrm{Lys}\right]$, and $m / z$ 138). The ion of $m / z 138$ in Figure $4 \mathrm{c}$ is probably due to significant rearrangements within the molecule. In Figure $4 b$, the cleavage of the $\mathrm{NH}-\mathrm{CH}_{2}$ bond two bonds removed from the $S$, which is characteristic of the presence of the $\left[\mathrm{CH}_{2} \mathrm{~S}\right]$ modification, is observed in significantly lower abundance than that of the comparable ion in the linear peptide. This fragment ion, fragment $f$ at $m / z 420$, corresponds to the loss of $-\left(\mathrm{CH}_{2}\right)_{2} \mathrm{SCHRCO}$ (where $\mathrm{R}=\mathrm{CH}_{2} \mathrm{C}_{6} \mathrm{H}_{5}$ ) from the protonated molecular ion.

\section{Thiomethylene Sulfoxide $\left(\mathrm{CH}_{2} \mathrm{SO}\right)$ Substitution}

Linear pseudopeptides that have been modified by a $\left[\mathrm{CH}_{2} \mathrm{SO}\right]$ replacement group exhibit a much more complicated spectrum upon CA than, for example, those containing the $\left[\mathrm{CH}_{2} \mathrm{~S}\right]$ modification. However, the decomposition pattern is still similar to that of the previously studied linear peptide (i.e., unmodified as well as $\left[\mathrm{CH}_{2} \mathrm{NH}\right]$ - and $\left[\mathrm{CH}_{2} \mathrm{SO}\right]$-modified peptides). For example, the CA spectrum of the $[\mathrm{M}+\mathrm{H}]^{+}$ion of Tyr-DAla-Gly $\psi\left[\mathrm{CH}_{2} \mathrm{SO}\right]$ Phe-Leu is shown in Figure $5 \mathrm{a}$. The presence of the N-terminal ions (i.e., $a_{n}$ and $b_{n}$ ions)

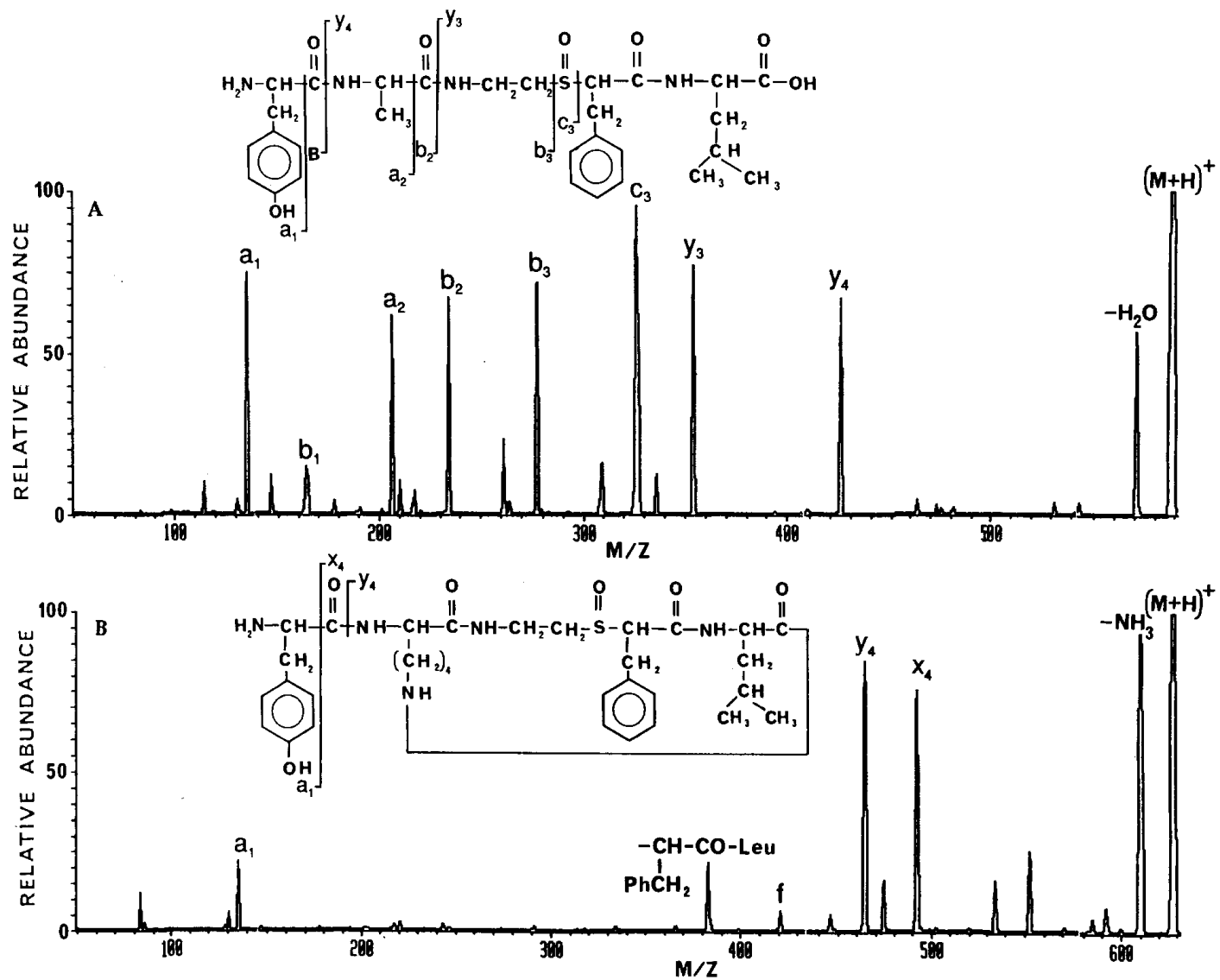

Figure 5. CAD spectra of the $[\mathrm{M}+\mathrm{H}]^{+}$ions of (a) Tyr-D-Ala-Gly $\psi\left[\mathrm{CH}_{2} \mathrm{SO}\right]$ Phe-Leu and (b) Tyrc[D-Lys-Gly $\psi\left[\mathrm{CH}_{2} \mathrm{SO}\right]$ Phe-Leu]. 
in high relative abundance is characteristic of the fragmentation patterns observed in unmodified peptides (Figure 1a) except that the $a_{4}$ and $b_{4}$ ions are not seen. In addition, the presence of the relatively abundant C-terminal sequence ions of $y_{3}$ and $y_{4}$ was also observed in the fragmentation of both the $\left[\mathrm{CH}_{2} \mathrm{NH}\right]$ - and $\left[\mathrm{CH}_{2} \mathrm{~S}\right]$-modified parent peptides (Figures $2 \mathrm{a}$ and $4 \mathrm{a}$, respectively). The sulfoxide group acts like a carbonyl group in that cleavages at the sulfoxide bond are observed (i.e., $b_{3}$ and $c_{3}$ ).

The MS/MS spectra of $\left[\mathrm{CH}_{2} \mathrm{SO}\right]$-modified cyclic peptides (Figure $5 \mathrm{~b}$ ) are also very similar to those of all the previously studied cyclic peptides in that the C-terminal ions of $y_{4}$ and $x_{4}$ are the most abundant fragment ions observed. In addition, as was observed in the CA spectra of $\left[\mathrm{CH}_{2} \mathrm{~S}\right]$-modified peptides, the daughter ion resulting from cleavage of the $\mathrm{NH}-\mathrm{CH}_{2}$ bond (two bonds removed from the substituted $\mathrm{CH}_{2}-\mathrm{SO}$ linkage) is observed. This ion at $m / z$ 420, fragment ion $\mathrm{f}$, corresponds to the loss of $-\left(\mathrm{CH}_{2}\right)_{2}$ SOCHRCO (where $\mathrm{R}=\mathrm{CH}_{2} \mathrm{C}_{6} \mathrm{H}_{5}$ ) from the $[\mathrm{M}+\mathrm{H}]^{+}$ion.

\section{Conclusions}

Upon CA, peptides containing modifications in the backbone chain undergo amino acid sequence fragmentations and side-chain fragmentations. Straightchain peptides containing $\psi\left[\mathrm{CH}_{2} \mathrm{NH}\right]$ and $\psi\left[\mathrm{CH}_{2} \mathrm{~S}\right]$ groups decompose to give predominantly $\mathrm{C}$-terminal ions. In comparison, $\psi\left[\mathrm{CH}_{2} \mathrm{SO}\right]$-modified linear peptides fragment to give a high relative abundance of both $\mathrm{N}$ - and C-terminal ions. However, the presence of a $\psi[\mathrm{CSNH}]$ group has little effect on the fragmentation of the peptide. In addition, the backbone-modified peptides tend to give relatively more abundant Cterminal fragment ions than the normal unmodified peptides. This effect may be less noticeable if other strongly directing groups, such as Arg or Lys [33], or charged residues are present. Since the daughter ion spectra of straight-chain peptides vary with the presence of the amide bond replacement, useful structural information may be obtained. The presence and location of the backbone modification can also be determined from the fragmentation pattern of the pseudopeptide. In contrast, the presence of a replacement group in the backbone of cyclic peptides can have less effect on the fragmentation patterns depending upon the presence or absence of exocyclic residues.

\section{Acknowledgments}

This work was partially supported by NIH grants GM-33376 (AFS) and NIDA-DA-04504 (AFS). Peptides used for these studies were primarily prepared by Mohmed K. Anwer, Krzysztof Darlak, J. Vincent Edwards, Fernando Formaggio, Claudio Mapelli, and Douglas B. Sherman. Initial portions of this work were also performed at the Midwest Center for Mass Spectrometry at the University of Nebraska, an NSF-sponsored facility.

\section{References}

1. Spatola, A. F. In Chemistry and Biochemistry of Amino Acids, Peptides and Proteins; Weinstein, B., Ed.; Marcel Dekker: New York, 1983; Vol. 7, pp 267-357.

2. Edwards, J. V.; Spatola, A. F.; Lemieux, C.; Schiller, P. W. Biochem. Biophys. Res. Commun. 1986, 136, 730-736.

3. Spatola, A. F.; Saneii, H.; Edwards, J. V.; Bettag, A. L.; Anwer, M. K.; Rowell, P.; Browne, B.; Lahti, R.; Von Voigtlander, P. Life Sci. 1986, 38, 1243-1249.

4. Clausen, K.; Spatola, A. F.; Lemieux, C.; Schiller, P. W.; Lawesson, S.-O. Biochem. Biophys. Res. Commun. 1984, 120, 305-310.

5. Spatola, A. F.; Formaggio, F.; Schiller, P. W.; Wire, W. S.; Burks, T. F. In Second Forum on Peptides; Aubry, A.; Marraud, M.; Vitoux, B., Eds.; INSERM/John Libbey Eurotext Montrouge, France: 1989; Vol. 174, pp 45-54.

6. Darlak, K.; Grzonka, Z.; Spatola, A. F.; Benovitz, D. E. Burks, T. F.; Wire, W. S. In Peptides, 1988-Proceedings of the 20th European Peptide Symposium; Jung, G.; Bayer, E., Eds.; Walter de Gruyter: Berlin, 1989; pp 632-636.

7. Spatola, A. F.; Mapelli, C.; Burks, T. L.; Wire, W. S.; Shook, J. In Recent Progress in the Chemistry and Biology of Biologically Active Peptides with Emphasis on Opioid Peptides; Dhawan, B. N.; Rapaka, R. S., Eds.; Central Drug Research Institute: Lucknow, India, 1988; pp 43-52.

8. Benovitz, D. E.; Spatola, A. F. Peptides 1985, 6, 257-261.

9. Biemann, K.; Martin, S. A. Mass Spectrom. Rev. 1987, 6, 1-76.

10. Burlingame, A. L.; Maltby, D.; Russell, D. H.; Holland, P. T. Anal. Chem. 1988, 60, 294R-342R.

11. Torgerson, D. F.; Skowronski, R. P.; Macfarlane, R. D. Biochem. Biophys. Res. Commun. 1974, 60, 616-621.

12. Roepstorff, P. Anal. Proc. 1987, 24, 365-366.

13. Winkler, H. U.; Beckey, H. D. Biochem. Biophys. Res. Commun. 1972, 46, 391-398.

14. Weber, R.; Levsen, K. Biomed. Mass Spectrom. 1980, 7, 314-316.

15. Matsuo, T.; Matsuda, H.; Katakuse, I.; Shimonishi, Y.; Maruyama, Y.; Higuchi, T.; Kubota, E. Anal. Chem. 1981, $53,416-421$.

16. Barber, M.; Bordoli, R. S.; Sedgwick, R. D.; Tyler, A. N. J. Chem. Soc., Chem. Commun. 1981, 325-327.

17. Chorev, M.; Gilon, N.; Roubini, E.; Ackerman, E.; LevianTeitelbaum, D.; Rosin, M. Collect. Czech. Chem. Commun. 1988, 53, 2519-2536.

18. Hunt, D. F.; Bone, W. M.; Shabanowitz, J.; Rhodes, J.; Ballard, J. M. Anal. Chem. 1981, 53, 1706-1708.

19. Barber, M.; Bordoli, R. S.; Sedgwick, R. D.; Tyler, A. N. Biomed. Environ. Mass Spectrom. 1982, 9, 208.

20. Amster, I. J.; Baldwin, M. A.; Cheng, M. T.; Proctor, C. J.; McLafferty, F. W. J. Am. Chem. Soc. 1983, 105, 1654-1655.

21. Hunt, D. F.; Yates, J. R., III; Shabanowitz, J.; Winston, S.; Hauer, C. R. Proc. Natl. Acad. Sci. U.S.A. 1986, 83, 6233.

22. Johnson, R. S.; Biemann, K. Biochemistry 1987, 26, 1209.

23. Eckart, K.; Schwarz, H.; Chorev, M.; Gilon, C. Eur. J. Biochem. 1986, 157, 209-216.

24. Dass, C.; Desiderio, D. M. Anal. Biochem. 1987, 163, 52.

25. Anderegg, R. J.; Carr, S. A.; Huang, I. Y.; Hiipakka, R. A.; Chang, C.; Liao, S. Biochemistry 1988, 27, 4214-4221.

26. Tomer, K. B.; Gross, M. L.; Zappey, H.; Fokkens, R. H.; Nibbering, N. M. M. Biomed. Environ. Mass Spectrom. 1988, $15,649-657$.

27. Biemann, K. Biomed. Environ. Mass Spectrom. 1988, 16, 99-111.

28. Tomer, K. B. Mass Spectrom. Rev. 1989, 8, 445-482.

29. Tomer, K. B. Mass Spectrom. Rev. 1989, 8, 483-511.

30. Gross, M. L.; McCrery, D.; Crow, F.; Tomer, K. B.; Pope, 
M. R.; Ciuffetti, L. M.; Knoche, H. W.; Daly, J. M.; Dunkle, L. D. Tetrahedron Lett. 1982, 23, 5381-5384.

31. Aubagnac, J. L.; Devienne, F. M.; Combarieu, R. Tetrahedron Lett. 1983, 24, 2263-2266.

32. Tomer, K. B.; Crow, F. W.; Gross, M. L.; Kopple, K. D. Anal. Chem. 1984, 56, 880-886.

33. Eckart, K.; Schwarz, H.; Tomer, K. B.; Gross, M. L. J. Am. Chem. Soc. 1985, 107, 6765-6769.

34. Nakamura, T.; Nagaki, H.; Kinoshita, T. Mass Spectrosc. 1986, 34, 307-319.

35. Deterding, L. J.; Moseley, M. A.; Tomer, K. B.; Jorgenson, J. W. Anal. Chem. 1989, 16, 2504-2511.

36. Deterding, L. J.; Srinivas, P.; Mahmood, N. A.; Burka, L. T.; Tomer, K. B. Anal. Biochem. 1989, 183, 94-107.
37. Tomer, K. B.; Guenat, C. R.; Deterding, L. J. Anal. Chem. 1988, 60, 2232-2236.

38. Tomer, K. B.; Guenat, C. R.; Dino, J. J.; Deterding, L. J. Biomed. Environ. Mass Spectrom. 1988, 16, 473-476.

39. Hass, J. R.; Green, B. N.; Bateman, R. H.; Bott, P. A. 32nd Annual Conference on Mass Spectrometry and Allied Topics, 1984; p 380 .

40. Johnson, R. S.; Martin, S. A.; Biemann, K. Int. J. Mass Spectrom. Ion Processes 1988, 86, 137-154.

41. Roepstorff, P.; Fohlman, J. Biomed. Environ. Mass Spectrom. 1984, 11, 601.

42. Lippstreu-Fisher, D. L.; Gross, M. L. Anal. Chem. 1985, 57, 1174-1180. 